\title{
NATIVESPEAKERISM AND WORLD ENGLISHES: TEACHERS PERCEPTION TOWARDS NON-NATIVE ENGLISH VARIETIES
}

\author{
Ronald Maraden Parlindungan Silalahi* \\ English Language and Culture Department, Bunda Mulia University, Jakarta \\ Received on 2 February 2021 / Approved on 16 April 2021
}

\begin{abstract}
In the last decade, the development of information technology confirms English as a Lingua Franca used by native English speakers and nonnative English speakers. English in a global context has triggered the emergence of new English variants, resulting from the assimilation of English into a local language known as World Englishes. On the other hand, Teaching English as a Foreign Language (TEAFL) in Indonesia is still oriented towards the ideology of nativespeakerism which believes that TEAFL should be done by Native English-Speaking Teachers (NEST) because they are believed to have better linguistic competence and contextual understanding than Nonnative English-Speaking Teachers (NNEST). This article is directed to determine the perceptions of English teachers in Indonesia regarding the world Englishes phenomenon. This research is qualitative research with 20 informants consisting of 10 Nonnative English-Speaking Teachers and 10 Native English-Speaking Teachers. Four Focus Group Discussions (FGDs), each consisting of 5 informants, will be conducted to gather as much information as possible related to teachers' perceptions. This research is expected to provide an overview of foreign language teaching in Indonesia. The results showed that nativespeakerism has a strong correlation with the world Englishes phenomenon. In the Indonesian context, this is shaped by the stigma that forms in society. This research is expected to enrich teaching studies, specifically in teaching foreign languages.
\end{abstract}

Keywords: Native Speakerism; world Englishes; varieties; teacher perception

\section{ABSTRAK}

Perkembangan teknologi informasi dalam satu dekade terakhir mengukuhkan bahasa Inggris sebagai Lingua Franca digunakan oleh penutur asli bahasa Inggris dan penutur bahasa Inggris non penutur asli. Penggunaan bahasa Inggris dalam konteks global telah memicu munculnya varian bahasa Inggris baru, akibat asimilasi bahasa Inggris ke dalam bahasa lokal yang dikenal dengan World Englishes. Di sisi lain, Teaching English as a Foreign Language (TEAFL) di Indonesia masih berorientasi pada ideology of nativespeakerism yang meyakini bahwa TEAFL harus dilakukan oleh Native English-Speaking Teachers (NEST) karena diyakini memiliki kompetensi linguistik yang lebih baik dan pemahaman kontekstual dari Nonnative English-Speaking Teachers (NNEST). Artikel ini diarahkan untuk mengetahui persepsi guru bahasa Inggris di Indonesia terhadap fenomena dunia bahasa Inggris. Penelitian ini merupakan penelitian kualitatif dengan 20 informan yang terdiri dari 10 Guru Penutur Bahasa Inggris Non Natif dan 10 Guru Penutur Bahasa Inggris Native. Empat Focus Group Discussion (FGD) yang masing-masing terdiri dari 5 informan akan dilakukan untuk mengumpulkan sebanyak mungkin informasi terkait persepsi guru. Penelitian ini diharapkan dapat memberikan gambaran tentang pengajaran bahasa asing di Indonesia. Hasil penelitian menunjukkan bahwa penutur asli memiliki korelasi yang kuat dengan fenomena dunia bahasa Inggris. Dalam konteks Indonesia, hal tersebut dibentuk oleh stigma yang terbentuk di masyarakat. Penelitian ini diharapkan dapat memperkaya khazanah dalam pengajaran studi, khususnya pengajaran bahasa asing.

Kata Kunci: Nativespeakerisme; World Englishes; varietas; persepsi guru

\footnotetext{
*Author(s) Correspondence:

E-mail: rsilalahi@bundamulia.ac.id
} 


\section{INTRODUCTION}

In recent decades, the rapid development of information technology has strengthened English as an international language and the lingua franca $(\mathrm{Wu} \& \mathrm{Ke}$, 2009; Crystal, 2003). In the global context, speaking English is an absolute must because English is used in various fields, such as economy, social, politics, and education.

The spread of English has led to various English variations (Balasubramanian \& Radwan, 2016). These new varieties are named by several terms, such as the Nonnative English variety, New Englishes, or World Englishes. In this article, the author uses the term introduced by Kachru (1984) at the Teachers of English to Speakers of Other Languages (TESOL) because it emphasizes English as a global language.

World Englishes can be seen as a form of recognition of new English variations from native (traditional) English (Balasubramanian \& AbuRadwan, 2016). The emergence of new English varieties can be seen as a reaction to traditional English deficiencies and as a form of rejection of the widely understood conceptions of Native English and Nonnative English (Rajagopalan, 2012).

Research on World Englishes has become a topic that is frequently discussed in the last few decades. Bauer (1989), Baumgardner (1996), Gisborne (2000), Bakshi (1991), Hosali (1991) are some of the names of researchers who researched several variations of English in Europe, New Zealand, and Asian countries. The studies on New Englishes leave many questions that remain unanswered comprehensively, namely, whether the new English varieties can be used as a model for teaching English and also who can claim the right to use English creatively when Nonnative English Speakers (NNESTs) produce their variations of English (Jenkins, 2015)

Scholars recognize the importance of a theoretical description of New Englishes, which can serve as a handbook and a pedagogical model used in classroom teaching
(Mukherjee \& Schilk, 2009). Erling (2005) emphasizes the importance of the New English Education model, which does not emphasize the privileges of English variations that belong into the inner circle category (American English and British English).

Attitudes towards the world Englishes phenomenon vary among researchers, teachers, practitioners, and learners (Balasubramanian \& AbuRadwan, 2016). Research on English as Foreign Language (EFL) in China and Taiwan shows that English language teaching tends to be oriented towards native or traditional English (which is included in the inner circle category) (Wang, 2016; Ren et al., 2015). Meanwhile, research on Philippine English variations shows a rejection of native or traditional English (Martin, 2014).

The identity of English as a global language should give freedom to the emergence of new variations. Erling (2005) states a need for a new ideology in teaching English that focuses more on English's global nature and its diversity. However, on the other hand, we still need native and standardized English as parameters and measuring tools to provide assessment in teaching. Therefore, language teachers and practitioners' attitude towards the world Englishes phenomenon is critical to study because they indirectly shape how they look at English and its variations (Rajagopalan, 2012: 380).

EFL in Indonesia is more oriented towards traditional native English. The ideology of teaching English in Indonesia tends to believe that native speakers must carry out the best learning model and teaching process because they are considered better competencies than Nonnative EnglishSpeaking Teachers (Silalahi, 2019). This ideology is a reflection of the phenomenon of Nativespeakerism. This phenomenon impacts the emergence of a negative stigma on the quality of NNEST (Holliday, 2005, 2006; Pennycook, 1994, 2002; Kubota, 2001; Silalahi, 2019).

Previous explanations portray the relationship between the New Englishes and the ideology of nativespeakerism. Therefore,

\footnotetext{
*Author(s) Correspondence:

E-mail: rsilalahi@bundamulia.ac.id
} 
to understand ELT teachers' perceptions in Indonesia towards the New Englishes phenomenon, research should start from the ideologies that develop in the context of ELT.

\section{LITERATURE REVIEW}

\section{World Englishes and English and Foreign Language}

In the early 1980s, several scholars created frameworks that became the basis for learning English as an international language (Guerra, 2014). There are three principles of teaching English as a global language that can be formulated, namely 1) knowledge of the social context and cultural context in communication events involving teachers or speakers from several cultures; 2) NEST needs to be equipped with knowledge about the use of English in a global context; 3) training and enrichment programs are necessary for NNEST regarding the use of English in a native context (Campbel et al., 1983; Guerra, 2014). The mastery of language as an international language focuses on the use of linguistic elements and cultural elements.

Modiano (2001) states that teaching English in an international context should focus more on building communication and less emphasis on cultural aspects, in particular on the variety of Native English [American English (AmE) and British English (BrE)]. Baxter (1991) adds that the material used in teaching English should consider various contexts of English use and not focus on L1. Kirkpatrick (2007) states that teaching English in circle countries should be oriented towards communication goals. Therefore, the curriculum used should include the culture of speakers who communicate in an intercultural context. Language teaching in the outer circle includes enriching knowledge and awareness of the various English variations worldwide.

\section{Nativespeakerism and Language Imperialism}

Linguistic imperialism in teaching English, which is oriented towards AmE and $\mathrm{BrE}$, can be seen as an impact of the ideology of nativespeakerism. Holliday (2005) defines nativespeakerism as an ideology in teaching English, which believes that teaching English should be done by NEST because it is believed to have better teaching and language competencies than NNEST.

The negative stigma against NNEST results from the cultural stigma associated with a language and culture (Silalahi, 2019). This cultural stigma develops in teaching and generates new stigmas related to the quality of NNEST teaching.

Rivers (2017), in his research on higher education teacher recruitment advertisements in Japan, mentioned the high preference for recruiting NEST. The status of native speakers can be seen as one factor that can increase educational institutions' promotional value. Imperialism in the context of language teaching can be seen clearly from the way an educational institution uses its power to determine policies. The recruitment policy that prioritizes native speakers clearly shows how this power relationship grows and develops in an educational institution.

\section{RESEARCH METHODOLOGY}

This article was written based on qualitative research conducted to describe English teachers' perceptions about the phenomenon of world Englishes and nativespekerism. Information gathering was carried out through Focus Group Discussions (FGD) with 20 informants who were English teachers in the English department at five private universities in Jakarta. The 20 informants in question consist of $10 \mathrm{NEST}$ and 10 NNEST. The 20 informants must meet the following criteria: 1) have taught English for at least two years, and 2) actively use English in the context of teaching, FGD was conducted before the corona pandemic (covid-19) in February 2020, so data collection was done face to face.

The FGD was divided into four sessions, each of which was conducted with five respondents.Informants who were invited two days before the FGD were sent a Term of

\footnotetext{
*Author(s) Correspondence:

E-mail: rsilalahi@bundamulia.ac.id
} 
Reference (TOR), which provided an overview of the topics to be discussed to understand, elaborate, and prepare themselves to answer the presented questions. The TOR was delivered personally without the knowledge of the institution where the informant worked. The TOR was delivered personally to minimize educational institutions' intervention towards the answers given by the informants.

Information gathering is carried out using the stimulus-respond method. Each session was divided into several discussions, starting with questions that acted as stimuli and the informants' answers as responses. After the stimulus (question) is delivered, the informant is asked to write down the answers briefly (1 to 2 sentences) on paper prepared previously. After writing down their answers on paper, the FGD leader invited each informant to explain the answers they wrote down. Other informants are allowed to support, reject, or refute statements made by other informants. Any information obtained during the FGD can be used as data in this study.

To assist with implementing the FGD, the FGD leader has provided a table containing several questions to guide. This table was given to respondents at the time the invitation was distributed. In the invitation, there was a text at the beginning (introduction) that provides an in-depth theoretical and practical description of nativespeakerism and New Englishes. The questions presented can be divided into two categories, namely World Englishes and Nativespekerism. This question is in line with the information presented in the Introduction and Literature Review sections above.

Table 1. List of Questions

\begin{tabular}{|c|c|c|c|}
\hline \multirow{2}{*}{ Categories } & \multicolumn{3}{|l|}{ Guide } \\
\hline & Questions & NEST & NNEST \\
\hline \multirow{7}{*}{ World Englishes } & $\begin{array}{l}\text { 1. Do you notice that there are variations of } \\
\text { English besides AmE and BrE? }\end{array}$ & $V$ & $V$ \\
\hline & $\begin{array}{l}\text { 2. If yes (question 1) can this new variation of } \\
\text { English be used as a model for teaching } \\
\text { English? }\end{array}$ & $V$ & $v$ \\
\hline & $\begin{array}{l}\text { 3. Do English teachers need to know the social } \\
\text { and cultural context of communication events } \\
\text { from a variety of social and cultural } \\
\text { perspectives? }\end{array}$ & $V$ & $V$ \\
\hline & $\begin{array}{l}\text { 4. Does NEST need to be equipped with } \\
\text { knowledge about the use of English in a } \\
\text { global context? }\end{array}$ & $V$ & \\
\hline & $\begin{array}{l}\text { 5. Does NNEST need training and enrichment } \\
\text { programs regarding the use of English in a } \\
\text { native context? }\end{array}$ & & $V$ \\
\hline & $\begin{array}{l}\text { 6. Do Teaching English in an International } \\
\text { Context should focus more on building } \\
\text { communication and less emphasis on AmE } \\
\text { and BrE? }\end{array}$ & $V$ & $V$ \\
\hline & $\begin{array}{l}\text { 7. Are the cultural aspects of teaching English } \\
\text { only to build learners' awareness of the } \\
\text { various variations of English around the } \\
\text { world? }\end{array}$ & $V$ & $V$ \\
\hline \multirow{3}{*}{ Nativespeakerism } & $\begin{array}{l}\text { 8. Do you believe that teaching English should } \\
\text { be done by NEST? }\end{array}$ & $V$ & $V$ \\
\hline & $\begin{array}{l}\text { 9. Does NEST have better teaching and language } \\
\text { competencies than NNEST? }\end{array}$ & $V$ & $V$ \\
\hline & $\begin{array}{l}\text { 10. Is a native speaker's status a factor that can } \\
\text { increase the promotional value for educational } \\
\text { institutions? }\end{array}$ & $V$ & $V$ \\
\hline
\end{tabular}

*Author(s) Correspondence:

E-mail: rsilalahi@bundamulia.ac.id 
Interviews are recorded in the waveform format (.wav) and transcribed according to the information needs in the analysis so that they can be used as references in writing articles.

\section{FINDINGS AND DISCUSSION}

The FGD provides an overall picture of the perception of NEST and NNEST towards the phenomenon of World Englishes and the ideology of nativespeakerism, which is further seen from the following description.

Question 1: Do you notice that there are variations of English besides AmE and BrE?

The first question raised during the FGD was whether NEST and NNEST recognized any English variation outside native English (AmE and BrE). All respondents indicated that there were variations in English outside the two native variations. However, some informants felt that it was better to use dialect terms rather than variations because the difference lay more in the way they were pronounced. Here is one of the direct statements from NEST in this regard.

English is spoken all over the world, so it is only natural that many new variations appear. I find this variation focuses more on the different ways of pronouncing it. The local language they use affects the English they speak (NEST 1).

However, some informants felt that the different variations were not only related to dialect but also grammar. One respondent gave an example of conveying an interrogative sentence in Singaporean English, heavily influenced by Mandarin or Cantonese. Informants provide information and examples that are different from one another.

If you are learning English, you should use American or British English. If you use English like Singaporeans, you can clearly see Chinese or Cantonese in the pronunciation. For example, if they want to ask, they will ask in the Chinese sentence [...] 'You going where ah?'; 'You know ah?' 'Eaten ah?' (NEST 2)

Informants' knowledge regarding this matter is influenced by the informant's experience of interacting with people from outer-circle countries, such as Singapore and India.

Question 2: If yes (question 1) can this new variation of English be used as a model for teaching English?

This question is a response to the first question that was asked before. This question is asked because basically all respondents are aware of the various English variations around the world.

NEST and NNEST argue that English variations can be used as models in learning. However, the variations in question should be language variations in the inner-circle countries (AmE and $\mathrm{BrE}$ ) and some outer circle counties that use English intensively. One respondent argued

Making New Englishes, a learning model, basically can be done, but it must be ensured that there are significant differences in terms of pronunciation and grammar. [...] In my opinion, before creating a learning model, the new variations must be standardized. There are dictionaries, grammar, and others (NNEST 1).

The author then asked the informants another question about the variations in the outer-circle countries whose English variations can be used as a learning model. The informant (NNEST 2) stated that English variations in India, Singapore, and the Philippines might be used as learning models because they use English every day. However, the influence of other languages must be considered. Other languages may affect accuracy in English. Further research is needed on whether these

*Author(s) Correspondence:

E-mail: rsilalahi@bundamulia.ac.id 
variations have differences with the two conventional variations (AmE and $\mathrm{BrE}$ ) in terms of pronunciation, grammar, and other aspects.

Question 3: Do English teachers need to know the social and cultural context of communication events from a variety of social and cultural perspectives?

30 percent of all informants (NEST and NNEST) stated that English teachers need to understand various social and cultural contexts. On the other hand, all respondents stated that it is impossible for classroom learning to enrich knowledge as a whole. Contextual enrichment of student knowledge can only be done through the natural learning process when a speaker communicates with people from different cultural and social backgrounds.

Question 4: Does NEST need to be equipped with knowledge about the use of English in a global context?

The informants' response to question 3 shows that teachers must have basic knowledge of AmE and BrE's culture. However, 40 percent of all respondents think that contextual knowledge only focuses on specific contexts, such as business, education, correspondence, and journalism. Learners should know contextual knowledge about business and correspondence because each country has its conventions related to business and correspondence systems. One respondent stated:

I think what needs to be learned is only things that are specific. For example, correspondence. [...] No need to thoroughly study all aspects (NNEST 3).

Question 5: Does NNEST need training and enrichment programs regarding the use of English in a native context?

\footnotetext{
*Author(s) Correspondence:

E-mail: rsilalahi@bundamulia.ac.id
}

The social and cultural background makes NNEST have limitations in using English in its natural context. Question 5 is aimed at facilitating the underlying shortcomings that NNEST has.

All respondents indicated that teaching and enrichment programs for NNEST related to the native context should be provided by educational institutions. To enrich NNEST's knowledge of English in its native context, however, this is not absolute because it can be studied directly by the teacher through various sources and literature.

All respondents feel it is essential to occasionally present material made or compiled by educational institutions or institutions from inner-circle countries. However, it should not be NNEST's top priority.

Question 6: Do Teaching English in an International Context should focus more on building communication and less emphasis on AmE and BrE?

In line with question 5, teaching English in an international context is more oriented to how people from various countries and cultures can communicate. Because it is intended for use in various countries, all respondents felt that this was not necessary. Teaching English for this purpose should be directed towards building communication that is mutually understandable to one another.

In line with this question, most respondents answered that the context of communication and the culture behind the communication event should be studied directly in the environment. So there is no need to learn specifically in class.

Question 7: Are the cultural aspects of teaching English only to build learners' awareness of the various variations of English around the world?

One of the NESTs stated that:

It is important to understand the culture owned by a country because it 
will enrich the knowledge of teachers. However, this should not be the main focus and goal of teaching English in an international context. Better, teaching is focused on building good and smooth communication (NNEST $3)$.

The FGDs with NEST and NNEST show that they recognize and acknowledge language variations outside of $\mathrm{BrE}$ and $\mathrm{AmE}$. However, they still question whether these other dialects are variations of English. Basically, respondents argue that the language variation can be used as a learning model, however, they still doubt whether this can be done because it is not certain that English speakers outside of AmE and BrE can use English properly. Most respondents feel that it is important to carry out cultural knowledge enrichment programs, but this cannot be done in the context of classroom learning. NEST is deemed necessary to have knowledge contextually regarding the use of language, for example, English in the context of correspondence. Learning English should put more emphasis on the role of language communication to be able to build understanding between participants. Understanding the culture and background is important to do, but fluent communication should be the focus.

\section{Nativespeakerism}

There is a correlation between Nativespeakerism and New Englishes. Attitudes towards the World English phenomenon differ among researchers, teachers, and practitioners. This phenomenon comes from the dichotomy of native and nonnative in the context of teaching English. Questions 8 to 10 are directed to determine perceptions of the ideology of nativespeakerism.

Question 8: Do you believe that teaching English should be done by NEST?

All respondents argued that NEST has a better contextual understanding than NNEST because it often uses English in its natural context. However, it is not certain that Native speakers have better teaching skills than NNEST. NEST and NNEST emphasize that everyone can become an English teacher as long as they have good English skills. Besides, teachers must also have good teaching skills so that they can handle classes well. One NNEST stated:

Basically, anyone can teach English in a global context. At the very least, teachers must have sufficient competence in English and teaching because language learning is not only related to language skills but also to teach these language skills. (NNEST 4)

Question 9: Does NEST have better teaching and language competencies than NNEST?

Silalahi (2019) states that the stigma associated with NNEST teaching quality is natural for Indonesia. The stigma is part of the culture in Indonesia. For all respondents, this is a stereotype that develops in society. Even though foreign speakers have used English since childhood and used it actively, it is not necessarily a speaker. However, to assume that NEST has a higher competency than NNEST is an overgeneralization. One NEST stated.

Overgeneralizing that all native speakers have better language skills and teach English is basically a mistake. Because it is not certain that all native speakers use the correct language, and it is not certain that foreign speakers can teach. (NEST 4)

Question 10: Is a native speaker's status a factor that can increase the promotional value for educational institutions?

Educational institutions in Indonesia still think that foreign teachers can increase the promotion of their educational institutions. The stigma is in line with the stereotype, which states that NEST has a higher language

\footnotetext{
*Author(s) Correspondence:

E-mail: rsilalahi@bundamulia.ac.id
} 
qualification than NNEST. One NNEST revealed that:

The perception that everything that comes from the west is better than the east is a natural thing in Indonesia. Therefore, Indonesia is a good target market. (NNEST 5)

\section{CONCLUSION AND SUGGESTIONS}

\section{Conclusion}

It cannot be denied that English has become a global language and has turned into a lingua franca. English is not only used by native English speakers but also by other speakers around the world. Interaction with other languages has led to the emergence of foreign language variations throughout the world. This paper shows that foreign speakers are still unable to determine and differentiate English dialects from Englishes. However, several dialects can be considered as variations of the English language. These dialects are used by many native and non-native speakers. The difference leads to a question about which variations can be used as a learning model. According to the English teacher's point of view, the variation used is the dominant English model used, namely AmE or BrE. However, learning English in a global context does not need to emphasize these two aspects because it focuses more on communication globally. Learning English in specific contexts is essential to know, but it is not the focus of learning because it can be built when learners use English in a native context. However, there is a specific context that learners need to know, for example, English in the context of correspondence, journalism, and others.

Nativespeakerism is related to the phenomenon of World Englishes. The stigma of Nativespeakerism focuses on the belief that English speakers have higher competence than non-native speakers. This research shows that this is a stigma built to strengthen promotion for educational institutions.

\section{Suggestions}

This study provides a picture of the stigma that appears to cultural background. Research on nativespekerism and English varieties demand is still being conducted by increasing the number of respondents.

\section{REFERENCES}

Bakshi, R. K. (1991). Indian English. English Today, 73(27)

Balasubramanian, C \& Radwan, A.A. (2018). New English Norms: A Reality or an Intellectual ideal? Journal of Arts and social Sciences.

Bauer, I. (1989). The verb have in New Zealand English. English World-Wide. 10

Baumgardner, R. (1996). Pakistani English: Acceptability and the norm. World Englishes. 14.

Baxter, J. (1991). How Should I Speak English? American-ly, Japanese-ly, or internationally?" Teaching English Pronunciation: a Book of Readings. Ed. Adam Brown. London: Routledge.

Campbell, D. (1983). Peansiri Ekniyom, Anjum Haque, and Larry Smith. English in International Settings: Problems and Their Causes. Readings in English as an International Language. Oxford: Pergamon Press.

Crystal, D. (2003). English as a Global Language. Cambridge: Cambridge University Press.

Erling, E. J. (2005). The many names of English. English Today, 21(1). 40-47.

Guerra, L (2014). Using Translation to Teach Native and Non-native Varieties of International English. e-TEALS: An ejournal of Teacher Education and Applied Language Studies.

Gisborne, N. (2000). Relative clauses in Hong Kong English. World Englishes, 19.

\footnotetext{
*Author(s) Correspondence:

E-mail: rsilalahi@bundamulia.ac.id
} 
Holliday A. (2005). The struggle to teach English as an international language. Oxford: Oxford University Press.

Holliday, A. (2006). Native-Speakerism. ELT Journal, 60(4), 385-387.

Hosali, P. (1991). Some syntactic and lexicosemantic features of an Indian variant of English. Central Institute of English and Foreign Languages Bulletin, 3(12), 65-83.

Jenkins, J. (2015). Repositioning English and multilingualism in English as a Lingua Franca. English in Practice, 2(3), 4985.

Kirkpatrick, A. (2007) World Englishes: Implications for International Communication and English Language Teaching. Cambridge: CUP.

Kubota, R. (2001). Discursive construction of the images of US classrooms. TESOL Quarterly, 35(1), 9-37.

Modiano, M. (2001). Ideology and the ELT Practitioner. International Journal of Applied Linguistics

Mukherjee, J. \& Schilk, M. (2009). Exploring variation and change in New Englishes: Looking into the International Corpus of English and beyond. In Vevalainen T. \& Traugott E (eds.) The Oxford Handbook of the History of English. Oxford: Oxford University Press.

Pennycook, A. (1994). The cultural politics of English as an international language. London: Longman.
Pennycook, A. (2002). Development, culture and language: ethical concerns in a postcolonial world. Proceedings of the 4th International Conference on Language and Development.

Rajagopalan, K. (2012). 'World English' or 'World Englishes'? Does it make any difference? International Journal of Applied Linguistics, 22(3).

Rivers, D. (2017). Native-speakerism and the betrayal of the native speaker teaching professional. In D. J. Rivers \& K. Zotzmann (Eds.), Isms in language education: Oppression, intersectionality and emancipation. Berlin: De Gruyter.

Ren, W., Chen, Y. \& Lin, C. (2016). University students' perceptions of ELF in mainland China and Taiwan. System, 56, 13-27.

Silalahi, R. M. P. (2019). Linguistic Imperialism: Native-Speakerism from The Perspective of Non-Native English Learners. Journal of ELT Research: The Academic Journal of Studies in English Language Teaching and Learning, 4(1), 73-84.

Wang, Y. (2016). Native English speakers' authority in English. English Today, 125(32), 35-40.

\section{Appendix}

Dear Informant,

My name is XXXXXX, I want to do research on nativespekerism and World Englishes. Therefore, I invite you to attend the Focus Group Discussion (FGD) which will be held on Tuesday, January 14, 2020. At 14.00 in Room R.301.

Thank you

*Author(s) Correspondence:

E-mail: rsilalahi@bundamulia.ac.id 
Introduction

Nativespeakerism and World Englishes are two linguistic phenomena that have often been discussed in recent years. Both can be seen as ideologies or beliefs related to English and learning English.

World Englishes is a form of acknowledgment of the existence of variations in English beyond traditional variations which divide English into American English (AmE) and British English $(\mathrm{BrE})$ or commonly known as inner-circle countries. The existence of this new variation raises a lot of controversies, regarding whether English learning should be oriented only to $\mathrm{AmE}$ and $\mathrm{BrE}$ or whether learning can be carried out by these new variations.

In teaching English to foreign speakers, the phenomenon of nativespeakerism is a belief that teaching English should be carried out by Native English Speaking Teachers (NEST) better than Nonnative English Speaking Teachers (NNEST) because they are believed to have better language and cultural knowledge. This leads to the question of whether NEST is of better quality than NNEST and what is the basis for the emergence of this ideology.

\section{Questions}

\begin{tabular}{|c|c|c|c|}
\hline \multirow{2}{*}{ Categories } & \multicolumn{3}{|l|}{ Guide } \\
\hline & Questions & NEST & NNEST \\
\hline \multirow{7}{*}{ World Englishes } & $\begin{array}{l}\text { 1. Do you notice that there are variations of } \\
\text { English besides AmE and BrE? }\end{array}$ & $V$ & $v$ \\
\hline & $\begin{array}{l}\text { 2. If yes (question 1) can this new variation of } \\
\text { English be used as a model for teaching } \\
\text { English? }\end{array}$ & V & $v$ \\
\hline & $\begin{array}{l}\text { 3. Do English teachers need to know the social } \\
\text { and cultural context of communication events } \\
\text { from a variety of social and cultural } \\
\text { perspectives? }\end{array}$ & V & $v$ \\
\hline & $\begin{array}{l}\text { 4. Does NEST need to be equipped with } \\
\text { knowledge about the use of English in a } \\
\text { global context? }\end{array}$ & V & \\
\hline & $\begin{array}{l}\text { 5. Does NNEST need training and enrichment } \\
\text { programs regarding the use of English in a } \\
\text { native context? }\end{array}$ & & $v$ \\
\hline & $\begin{array}{l}\text { 6. Do Teaching English in an International } \\
\text { Context should focus more on building } \\
\text { communication and less emphasis on AmE } \\
\text { and BrE? }\end{array}$ & V & $v$ \\
\hline & $\begin{array}{l}\text { 7. Are the cultural aspects of teaching English } \\
\text { only to build learners' awareness of the } \\
\text { various variations of English around the } \\
\text { world? }\end{array}$ & V & V \\
\hline \multirow{3}{*}{ Nativespeakerism } & $\begin{array}{l}\text { 8. Do you believe that teaching English should } \\
\text { be done by NEST? }\end{array}$ & $V$ & V \\
\hline & $\begin{array}{l}\text { 9. Does NEST have better teaching and language } \\
\text { competencies than NNEST? }\end{array}$ & $V$ & $V$ \\
\hline & $\begin{array}{l}\text { 10. Is a native speaker's status a factor that can } \\
\text { increase the promotional value for educational } \\
\text { institutions? }\end{array}$ & V & $V$ \\
\hline
\end{tabular}

*Author(s) Correspondence:

E-mail: rsilalahi@bundamulia.ac.id 